\title{
A study on analysis of yield gap in pulses of Nadia district of West Bengal, India
}

\section{Ome Jopir* and B. K. Bera}

Department of Agricultural Economics, Bidhan Chandra Krishi Viswavidyalaya, Mohanpur, Nadia-741252 (West Bengal), INDIA

*Corresponding author. E-mail: ojopir@yahoo.in

Received: March 13, 2016; Revised received: February 6, 2017; Accepted: April 2, 2017

Abstract: The study on yield gap in pulses (Lentil) of West Bengal revealed that the technology gap is accounted to be $346.23 \mathrm{~kg} / \mathrm{ha}$ and technology index and the index of realised potential yield are estimated to 22.56 and $77.44 \%$, respectively. The extension gap and the index of realised potential farm yield are $215.12 \mathrm{~kg} / \mathrm{ha}$ and $81.9 \%$, respectively. Lentil cultivation generates a net return of ₹ 47083.07/ha from an investment of $₹ 29640.30 /$ ha in experimental field whereas an expenditure accounting ₹ 23240.76 and $₹ 18559.71 /$ ha are made in demonstration and actual farmer's field to realise a net return of ₹ 36171.44 and $₹ 30096.79 / h$. Although, the most viable alternative crop, rape and mustard has marginal advantage over lentil economically, considering the long term beneficial effects of pulses soil fertility, programmes need to be taken to motivate farmers to allocate more area to pulses. Low productivity and non-availability of quality occupy the first and second position with 82.73 and $71.25 \%$ Garrett's score constructed based on the perception of sample farmers. Development of improved seeds responsive to modern crop production technology is the most vital for long term solution of the present crisis in pulses, but for the time being, programmes for technology dissemination and adoption through various extension methods is necessary in bridging the extension gap to improve the pulses situation of West Bengal.

Keywords: Extension gap, Garrett score, Multiple regression and Technology gap

\section{INTRODUCTION}

Pulses, an important constituent of food grains, play a vital role in food and nutritional security of millions of down trodden people of the world. Being an important source of protein, poor people mostly depends on pulses for meeting their daily requirements of this essential nutrient. Pulses will form a major source of protein for a huge section of Indian particularly, for the poor, backward classes of the traditionally vegetarian population (Reddy, 2004). But in reality, the net availability of pulses has come down from 61 to $37 \mathrm{gm} /$ day/person and daily per capita consumption has come down from about 74 grams to 23 grams during the period 1960-61 to $2009-10$ as against the ICMR norms of $40 \mathrm{gm} / \mathrm{day} /$ person over the period 1950-51 to 2008-2009 in India, although, the World Food Programme (WFP) includes 60 grams of pulses in its typical food basket alongside cereals, oils, sugar and salt due to huge demand-supply gap. India is reckoned as the largest producer and consumer of pulses in the world accounting 25 per cent of that global production, 27 per cent of consumption and 34 per cent of food use (Price et al., 2003). The new crop production technology popularly known as seedfertilizer-water technology have also failed to augment the productivity of the crop as in case of cereals, particularly rice and wheat i.e. new technology has by passed the pulses. To meet the domestic requirement of 26.50 MT in 2050, pulses production needs to be increased by 1.86 per cent annually as against the current growth rate of only 0.6 per cent. If the area growth remains constant which is currently negative $(-2.05$ $\%$ ), annual growth rate in productivity will be required to achieve 26.5 MT by 2050 (Ali and Gupta, 2012). The state, West Bengal, has currently produced $1.77 \mathrm{~m}$ tons of pulses from an area of $1.97 \mathrm{~m}$ ha with the yield rate of about $997.46 \mathrm{~kg} / \mathrm{ha}$. Lentil (masur), khesari, gram and mung are the dominant pulses in the state and Nadia, Murshidabad, Malda, Purulia and two northern districts, namely, Cooch Behar and Jalpaiguri are the leading pulses growing districts. Lentil, popularly known as masur, is the dominant pulse crop in West Bengal accounting 30.24 per cent of the total pulses production of the state from an area share of 29.12 per cent. Again, Nadia district ranks first by claiming 42.15 per cent of total lentil production of the state followed by Murshidabad (26.86 \%) and subsequently followed by Birbhum $(6.58 \%)$ and Malda $(6.17 \%)$. To achieve the targeted growth in productivity, the domestic yield must be elevated to level of some importing countries, at least to the level of potential yield obtained by the scientists in various research stations of the country as well as in the state. Hence, yield gap analysis is a useful guide to establish 
research priorities for rice, wheat and pulses crop through knowledge of yield limiting factors and their influence on yield (Singh, 2001) and assessment of potential yield and yield gaps can help in identifying the yield limiting factors and in developing suitable strategies to improve the productivity of a crop (Aggarwal and Kalra, 1994; Evans et al., 1993; Naab et al., 2004). Once the yield gap between waterlimiting yield and actual yield is determined, then the relative contribution of other major constraints and limitations causing yield gap can be assessed in order to focus on the priority research or crop management needs to bridge the yield gap (Singh, 2001). In West Bengal, pulses are grown in almost all districts, though the area is declining grossly over the decades (Bera and Nandi, 2010). Considering the importance of the crops, International Centre for Agriculture Research in Dry Areas (ICARDA) in association with Bidhan Chandra Krishi Viswavidyalaya (BCKV), West Bengal has taken up intensive research to develop suitable varieties of lentil, khesari, gram and mung and organising extensive demonstration programmes to popularise the crops among the farmers of the state especially in areas of moisture stress. In this context, the present study is undertaken with the specific objectives: i) To assess the yield gap in lentil using various techniques in Nadia district of West Bengal, (ii) To estimate relative profitability of lentil cultivation compared to competing crops, (iii) To identify the factors responsible for variation in yield differences of lentil and, (iv) To suggest some policy measures for stepping up pulses production in West Bengal.

Table 1. Estimates of yield gap between Research station (Potential) and Demonstration.

\begin{tabular}{lc}
\hline Particulars & Yield (Kg/ha) \\
\hline Research Station & 1534.48 \\
Demonstration plot & 1188.25 \\
Technology gap (Yield gap-I) & 346.23 \\
Technology Index (\%) & 22.56 \\
Index of realized potential farm yield (\%) & 77.44 \\
\hline
\end{tabular}

Table 2. Estimates of yield gap between Demonstration yield and Farmer's plot yield.

\begin{tabular}{lc}
\hline Particulars & Yield(Kg/ha) \\
\hline Farmer's plot yield & 973.13 \\
Demonstration yield & 1188.25 \\
Yield gap-II (Extension gap) & 215.12 \\
Yield gap (\%) & 18.10 \\
Index of realized farm yield (\%) & 81.90 \\
\hline
\end{tabular}

Table 3. Estimates of yield gap between Potential yield and Farmer's plot yield.

\begin{tabular}{lc}
\hline Particulars & Yield (Kg/ha) \\
\hline Research Station & 1534.48 \\
Farmer's plot yield & 973.13 \\
Yield gap-III & 561.35 \\
Yield gap (\%) & 36.58 \\
Index of realized yield (\%) & 63.42 \\
\hline
\end{tabular}

\section{MATERIALS AND METHODS}

Primary data related to costs and returns of pulses (lentil) and rape and mustard has been collected from 60 farmers belonging to purposively selected four villages of Haringhata block of Nadia district of West Bengal, 30 from each of the owners of demonstration plot (Front line demonstration) and farmers growing lentil by traditional system following Simple Random Sampling without Replacement (SRSWOR) technique in well-structured pre-tested schedule through personal interview method. Information relating potential yield and yield in the demonstration field is collected from the experiment results of varietal development of lentil and front line demonstration conducted by scientists of this university in association with ICARDA. The reference period for the study is 2013-14.

For the study, technology gap, extension gap and technology index will be estimated using formula suggested by Samui et al. (2000).

Multiple regression technique is employed to find out factors responsible in yield gap of lentil produced by sample farmers in different farming situations.

Garrett's score:

The assigned rank given by the respondent to a specific problem is converted into percentage position which subsequently transferred into Garrett's score using Garrett's table. For each constraint, scores of individual respondent are added together and divided by the number of respondents to obtain a mean score for each constraint.

Percentage position $=100\left(\mathrm{R}_{\mathrm{ij}}-0.5\right) / \mathrm{N}_{\mathrm{j}}$, Where, $\mathrm{R}_{\mathrm{ij}}=$ Rank given for the $\mathrm{i}^{\text {th }}$ item by the $\mathrm{j}^{\text {th }}$ individual, $\mathrm{N}_{\mathrm{j}}=$ Number of items ranked by the $\mathrm{j}^{\text {th }}$ individual

\section{RESULTS AND DISCUSSION}

At the outset, we will examine the yield gap between potential and demonstration plot yield; potential yield and famer's plot yield, and demonstration and farmer's plot yield of pulses with a view to identify the socioeconomic, soil and management factors limiting current farm yield and impact of improved farm management practices for narrowing the gap. Effective prioritisation of research, development and intervention is another objective in studying the yield gap of pulses of West Bengal. Without yield gap assessment coupled with appropriate socio-economic analysis of constraints to improve productivity, policy makers and researchers will find it difficult to accurately assess future food security and land use change. In a situation when area under pulses showing continuous declining trend, growth rate of area and production is negative and associated year- to -year fluctuation is very high, the gap between demand and supply is widening leading to galloping rise in prices which is indirectly affecting the food and nutritional security of millions of Indian to whom pulses are the rich source of protein. 
Table 4. Estimation of cost and return of lentil cultivation in the research plot in the research station, field of demonstration field and actual farmer's field.

\begin{tabular}{lccc}
\hline Particulars & Researcher's Plot & Demonstration Plot (Rs/ha) & Farmer's plot (₹/ha) \\
\hline Seed & $2450.00(8.27)$ & $2450.00(10.54)$ & $2462.69(13.27)$ \\
Chemical Fertilizer & $2045.47(6.90)$ & $2045.47(8.80)$ & $502.99(2.71)$ \\
Manures & $625.73(2.11)$ & $312.50(1.34)$ & 0.00 \\
Plant protection Chemicals & $1352.75(4.56)$ & $678.52(2.92)$ & $298.51(1.61)$ \\
Irrigation & $2054.56(6.93)$ & 0.00 & 0.00 \\
Human labour & $12472.44(42.08)$ & $10125.00(43.57)$ & $8507.46(45.84)$ \\
Bullock labour or power tiller & $5672.62(19.14)$ & $5243.75(22.56)$ & $4746.27(25.57)$ \\
Miscellaneous & $2967.36(10.01)$ & $2385.52(10.26)$ & $2041.79(11.00)$ \\
Total cost & $29640.30(100.00)$ & $23240.76(100.00)$ & $18559.71(100.00)$ \\
Total return & 76724.00 & 59412.20 & 48656.50 \\
Physical Output (Kg/ha) & 1535.48 & 1188.25 & 973.13 \\
Net return & 47083.07 & 36171.74 & 30096.79 \\
Return-Cost ratio & 2.56 & 2.59 & 2.62 \\
Cost of production & 1931.01 & 1956.29 & 1907.47 \\
\hline
\end{tabular}

Table 5. Estimates of costs and returns obtained from lentil and mustard cultivation by sample farmers (₹/ha).

\begin{tabular}{lcc}
\hline Particulars & Lentil & Mustard \\
\hline Seed & $2462.69(13.27)$ & $189.120 .96)$ \\
Chemical fertilizer & $502.99(2.71)$ & $2427.89(12.28)$ \\
Manures & $00.00(0.00)$ & $680.27(3.44)$ \\
Plant protection chemicals & $298.51(1.61)$ & $551.02(2.79)$ \\
Irrigation & $00.00(0.00)$ & $357.14(1.81)$ \\
Human labour & $8507.46(45.84)$ & $11346.94(57.39)$ \\
Bullock labour or Power tiller & $4746.27(25.57)$ & $2329.94(11.78)$ \\
Miscellaneous & $2041.79(11.00)$ & $1888.23(9.55)$ \\
Total cost & $18559.71(100.00)$ & $19770.55(100.00)$ \\
Total return & 48656.50 & 52030.30 \\
Physical output $(\mathrm{Kg} /$ ha) & 973.13 & 1486.58 \\
Net return & 30096.79 & 32259.75 \\
Return-cost ratio & 2.62 & 2.63 \\
Cost of production & 1907.47 & 1329.94 \\
\hline
\end{tabular}

Under this context, yield gap analysis of pulses becomes pertinent to find productivity limiting factors to close the gap which will ultimately reduce demandsupply through improvement in total production. In absence of HYV of pulses that responds positively like cereals to modern crop production technology, research and extension programme for narrowing the gap is a viable alternative in augmentation of production of pulses. The assessment of yield potential and yield gaps can help in identifying limiting factors and develop strategies to improve crop productivity (Aggarwal and Kalra, 1994; Bhatia et al, 2008). Yield gap analysis can be conducted at two stages- Yield gap -I and Yield gap-II (Singh, 2011). Yield gap-I refers to the difference between research station yields and potential farmer's yield obtained at demonstration plot in a particular region and the difference between yield obtained at the nearest demonstration plot and average yield obtained at farmer's field in a particular region is designated as Yield gap-II. This gap reflects a series of bio-physical and socio-economic constraints. (Bhattacharya, 2011) analysed yield gap at three stages: Yield gap-I (difference between potential yield and national average yield), Yield gap-II (difference between potential yield and state average yield) and Yield gap-III (difference between potential yield and on-farm yield). In the present study, we have used three measures of yield gap analysis: Yield gap-I refers to the difference between the yield obtained at the research station and demonstration plot yield; Yield gapII is the difference in yield between demonstration plot and the yield realised by the farmer's in the nearby region and Yield gap-III indicates the difference in yield between research plot and farmer's field.

Table 1 reveals that the average potential yield or maximum attainable yield of pulses is observed to be $1534 \mathrm{~kg} / \mathrm{ha}$ whereas the yield obtained from the demonstration plot is $1188.25 \mathrm{~kg} / \mathrm{ha}$. So, the technology index is estimated to 22.56 percent i.e. yield realised at the research station is 22.56 per cent higher than that of demonstration plot although FLD's are conducted under the strict supervision of the scientist in the farmer's field using same technology as applied in the research station. The technology gap which is the difference between yield realised at the research station and demonstration plot is $346.23 \mathrm{Kg} / \mathrm{ha}$.

This estimated Yield gap-I may be attributed to the variation in soil fertility, micro-climate and problems related to diseases control. Technology gap may be due to lack of irrigation facilities, variation in soil fertility status, non-congenial weather conditions and location specific and Chandra, 2004; Vaghasia et al., 
Table 6. Ranking of Constraints based on the perception of sample farmers.

\begin{tabular}{|c|c|c|}
\hline Constraints & Garrett'score Score & Rank \\
\hline Low productivity of seed & 82.73 & $\mathrm{I}$ \\
\hline Non-availability of quality seed & 71.25 & II \\
\hline Higher prices of seeds & 49.66 & $\mathrm{~V}$ \\
\hline Lack of knowledge related improved package of practices & 65.83 & III \\
\hline Non-availability of irrigation water & 28.23 & $\mathrm{X}$ \\
\hline Marketing problem & 34.28 & IX \\
\hline Non-remunerative prices & 51.78 & IV \\
\hline High cost of fertilizer & 39.55 & VII \\
\hline Disease problem & 45.97 & VI \\
\hline Non-availability of rhizobium inoculation & 37.29 & VIII \\
\hline
\end{tabular}

2005). The technology gap may be attributed to the dissimilarity in soil fertility status and weather conditions (Mukherjee, 2003). This gap is caused by the differences in climate, soil and other physical environment factors, which are difficult to manage in demonstration farmer's field (Singh, 2011). Index of realised potential yield measuring the percentage of the yield potential achieved in the demonstration plot is calculated to be 77.44 per cent. It indicates the scope of further improvement in the yield of demonstration plot by minimising the variation in the soil fertility status between them.

Again, under almost similar agro-climatic situation and soil fertility, yield of pulses in demonstration plot is found to be $1188.25 \mathrm{Kg} / \mathrm{ha}$, although farmer's plot yield is $973.13 \mathrm{Kg} / \mathrm{ha}$ i.e. the extension gap or Yield gap-II is $215.12 \mathrm{Kg} / \mathrm{ha}$. So, the farmers of demonstration plot have realised 18.10 per cent higher rate yield in comparison to their counterparts growing lentil by traditional system. The higher yield in demonstration plot may be attributed to the fact that farmers of demonstration plot have followed the same techniques that are used in research plot like line sowing, seed treatment with rhizobium, recommended fertilizer doses, plant protection measures, etc. Higher yield of chickpea and lentil in demonstration plot is due to line sowing with optimum spacing, improved variety with optimum seed rate, rhizobium inoculation, optimum fertilizer application and proper weed control (Rajiv and Singh, 2014). The demonstration conducted on lentil with improved varieties and technologies showed a yield advantage of about 33 per cent over local check (Kokate et al., 2013). Rhizobium inoculation alone can increase the yield of chickpea, pigeon pea, lentil and field pea by 12.5, 14.0, 18.1 and 20.6 per cent (Ali and Kumar, 2007), but in traditional system the sample farmers do not apply seed treatment with rhizobium resulting lower yield. Farmers did not practice seed treatment with rhizobium culture, an important component increasing the yield and yield attributes (Kumar and Elamathi, 2007). This type of gap arise when farmers deviate from the recommendation to achieve the agronomic yield potential (Duwayri et al., 2000), although it is exploitable if variation in soil fertility is minimised through proper management of soil health. A small yield gap indicates the available technologies are almost fully used (Nin-pratt et al., 2010). On the other hand, a large Yield gap-II implies that farmer did not fully adopt the existing technologies because they were not packaged appropriately or because economic condition made them unattractive (Pingali and Heirey, 1999). In the present case, farmers have precisely applied the technology under the strict supervision of scientists and become able to keep yield gap at the lowest level.

An attempt has also been made to find out the yield difference between potential and actual average farm yield which is designated here as Yield gap-III. Table-3 reveals that the sample farmers have harvested average yield of lentil amounting $973.13 \mathrm{Kg} / \mathrm{ha}$ whereas potential yield is $1534.48 \mathrm{Kg} /$ ha i.e. yield of lentil in actual farming situation is $561.35 \mathrm{Kg}$ /ha less than maximum attainable yield. On the other side, potential yield is 36.58 per cent higher than that harvested by farmers in actual field. The index of realised potential farm yield measured as a percentage of potential yields is estimated to be 63.42 per cent i.e. the sample farmers have been able to realise only 63.42 per cent of the potential yield.

This gap in yield may be attributed to the poor adoption of technology encompassing seed rate, seed treatment, fertilizer application, disease control and lentil varieties, variation in micro climate, etc. Differences in farmer's management practices, infrastructural facilities and planning at macro level influenced the yield gap (Sarungham and Prasad, 2011). So yield of lentil in actual farmer's field can be increased by $561.35 \mathrm{Kg} / \mathrm{ha}$ through effective dissemination of improved technology. The field level demonstration has proved its efficacy in raising productivity of lentil and also provided the researcher's an opportunity to demonstrate the productivity potential and profitability of the latest technology under real farming situation. An average extension gap is observed to be $5.05 \mathrm{q} / \mathrm{ha}$ which emphasized the need to educate the farmers through various extension means, i.e. front line demonstration for adoption of improved production and protection technologies, to revert the trend of wide extension gap (Singh et al., 2014). So, the available agricultural technology generated in the research station does not serve the very purpose until it is disseminated and adopted by its ultimate users, the farmers. The huge gap in 
Table 7. Coefficient of variables used in the cultivation of lentil.

\begin{tabular}{lcc}
\hline Variables & Co-efficient & t-value \\
\hline Seed & $0.783^{*}$ & 1.155 \\
Chemical fertilizer & $0.101^{*}$ & 1.442 \\
Manures & 0.075 & 0.223 \\
Plant protection chemicals & -0.870 & -0.237 \\
Human labour & -0.332 & -0.737 \\
Bullock labour or Power tiller & $0.224^{* *}$ & 0.543 \\
\hline
\end{tabular}

yield between research station and farmer's field may be attributed to the several biotic and abiotic and socio -economic constraints inhibiting the exploitation of the yield potential and most of these can be effectively addressed through proper dissemination of well packaged technology. Low yield of lentil is mainly due to non-availability of quality seeds in one hand, poor knowledge about recently developed technologies and their management practices on the other. Adoption level of several components of the improved technology was low, emphasizing the need for better dissemination.

We will now examine the differences in cost and returns structure of lentil cultivation in three situations i.e. in research station, demonstration plot and farmer's plot under real farming situation with a view to estimate the economic impact of the observed yield gap. The costs and return structures estimated by taking into account only out of pocket costs (prime cost concept) for three different situation discerns that a total investment of Rs. 29640.30 is required to produce an average output of 15.35 quintals of lentil per ha in research station whereas 11.88 and 9.73 quintals output is obtained from demonstration plot and actual farmer's field producing lentil practising traditional system by incurring an expenditure of Rs. 23240.76 and Rs. 18559.71 per ha respectively (Table 4). Although, expenses on all categories of inputs is the highest in research station followed by demonstration plot and farmer's field in absolute monetary terms and their percentage contribution to respective total cost of cultivation per ha also shows similar trend. The share of human labour or bullock labour, a power tiller, seeds and miscellaneous items in the total cost is estimated to be higher in actual farmer's field accounting 45.84, $25.57,13.27$ and 11.00 per cent respectively compared to that of demonstration plot $(43.57,22.56,10.54$ and $10.26 \%$, respectively) and research station (42.08, $19.14,8.57$ and $10.01 \%$, respectively). But expenses on irrigation, chemical fertilizers, manures and plant protection chemicals claim higher percentage share of the total cost in research station which is accounted to be $6.93,6.90,4.56$ and 2.11 per cent respectively in comparison to their counterparts in demonstration plot $(0.00,8.80,2.92$ and $1.34 \%$ respectively) and actual farmer's field $(0.00,2.71,1.61$ and $0.00 \%$ respectively). This variation in percentage contribution among the three situations is due to the fact that cultivation of lentil in demonstration plot and farmer's field is completely under rainfed condition and sample farmers in actual farming situation do not apply manures and cost on chemical fertilizers, plant protection chemical is negligible in the later which have reflected in the variation in percentage share of inputs in the corresponding cost of cultivation of lentil.

Most of sample farmers producing lentil by traditional system does not apply any chemical fertilizers and plant protection chemicals, manures and irrigation resulting lower cost of cultivation compared to demonstration field and research station. Cost of human labour and tillage is also lower because of lack of knowledge regarding the importance of proper land preparation and intercultural operation in augmenting productivity of lentil. On the other hand, farmers of demonstration plot, though follow newly developed technologies, but become able to keep total cost lower comparative to research station due to dependence on family supplied human and bullock labour and application of plant protection chemicals at low doses along with absence of irrigation charges. Net return realised from research station, demonstration and farmer's field are accounted to be ₹ 47083.07, ₹ 36171.44 and ₹ 30096.79 per ha from a total return of ₹ 76724.00 , ₹ 59412.20 and $₹ 48656.50$ per ha, respectively, although return-cost ratio measuring return from one rupee investment is observed to be the highest in case of actual farmer field (2.62) compared to demonstration plot (2.59) and research station (2.56). The cost of production of lentil varies between ₹ 1900 to ₹ 2000 per quintal. It is the lowest ( $₹ 1907.47 /$ q) in case of farmer's field followed by research station ( $₹$ 1931.01/ q) and demonstration plot (₹ 1956.29/q). So, the total return and net return is directly proportional to the total cost of cultivation per ha estimated by using prime cost concept. In the study region, boro rice, onion and rape and mustard are the competing crops which the sample farmers can take up in place of lentil. Actually, farmers favours boro rice or at least onion cultivation in land with assured irrigation facilities. But in high land situation having difficulty in irrigating the crop, farmers opt for either lentil or rape and mustard. So, the main competing crops of lentil are mustard in the identical land situation. Taking rape and mustard as a viable alternative of lentil, we will make an attempt to examine the relative economics of cultivation of these two competitive crops in order to find out the superiority of one to other in economic terms. Table 5 demonstrates that sample farmers have made an expenditure of ₹ 19770.55 to harvest a physical yield of $14.87 \mathrm{q} /$ ha of rape and mustard whereas ₹ 18559.71 has been spent by the same farmer to realise a yield of $973 q /$ ha of lentil. Wages of human labour is found to be the most dominant cost component in both the cases, but the percentage share to the total cost is observed to be higher in case of former compared to 
the later. Expenditure on chemical fertilizers is the second highest cost component claiming 12.28 per cent of the total cost of mustard cultivation whereas in case of lentil cultivation, cost of tillage comes next after human labour $(25.57 \%)$ and cost of chemical fertilizers is negligible $(2.71 \%)$. Expenses on inputs such as bullock labour, miscellaneous charges, manures, plant protection chemicals, irrigation and seeds come next when arranged in descending order their percentage contribution to total cost of cultivation of mustard whereas in case of lentil, the sequence is seed, miscellaneous, chemical fertilizer, plant protection chemical, etc arranged in same order. Total return realised from mustard and lentil cultivation is accounted to be ₹ 52030.30 and ₹ 48656.50 from the physical output of 14.87 and $9.73 \mathrm{q} /$ ha respectively. Net returns are estimated to be ₹ 32259.25 and ₹ 30096.79 /ha, respectively and the corresponding return-cost ratios are 2.63 and 2.62. Although, the cultivation of mustard has slight edge over lentil in terms of net returns and return-cost ratios, but the actual margin is very negligible considering small size of the land under cultivation of each crop, which leave them in the same position in the scale of preferences of farmers. Actually, farmers grows both the crops to meet the requirement of family and the surplus amount, if any, sell in the market to recover a part of the cost of cultivation.

Constraints analysis: In this section, we will discuss the problem and constraints hindering the enhancement in area and production of pulses based on the perception of farmers. Garrett ranking technique is applied in prioritising the problems faced by sample farmers. Low productivity of pulses has emerged as the

most dominant problems with Garrett score 82.73 per cent (Table 6). The second most important constraint according to the respondent's perception is the nonavailability of quality seed with Garrett's score 71.25 per cent. Lack of knowledge regarding improved package of practices with Garrett's score 65.83 percent is the third important constraint impeding the augmentation of pulses production. The reason for low productivity are poor knowledge about newly released crop production and protection technologies and their management practices in the farmers field (Meena et al., $2012)$. Non-remunerative price $(51.78 \%)$, higher prices of seeds $(49.66 \%)$, problems related to diseases (45.97\%), high cost of fertilizer (39.55\%), nonavailability of rhizobium culture for seed inoculation (37.29 \%), marketing problems $(34.28 \%$ ) and nonavailability of irrigation water $(28.23 \%)$ come next when arranged in descending order of the Garrett's score constructed based on the perception of sample farmers.

Regression analysis: Here, an attempt has been made to find out the factors responsible for differences in yield between demonstration plot and actual farmers field. For this purpose, multiple regression analysis technique has been employed. The fitted equation is given as follows:

$\mathrm{Y}=6651.45+0.783 * \mathrm{X}_{1}+0.101 * \mathrm{X}_{2}+0.075 \mathrm{X}_{3}-$ $0.087 \mathrm{X}_{4}-0.332 \mathrm{X}_{5}+0.244 * * \mathrm{X}_{6}$

Table 7 discuss that the co-efficient of both seed and chemical fertilizers are positive and significant at 5 per cent level implying that the yield gap between them is directly influenced by these two variables. Tillage operation is also responsible for yield gap as it has positive coefficient value but with 10 per cent level of significance. The coefficient value of plant protection chemicals and human labour is negative, but nonsignificant indicating adverse effect on yield gap.

Suggestions for stepping up pulses production: With the passage of time, excessive use of chemical fertilizers and irrigation in rice and wheat to maintain their productivity has created an imbalance in soil fertility and threatened the sustainability of the most productive food grain belt in South Asia [Hobbs and Morris 1996].So the time has come to reverse the trend for the betterment of the economy in the future by increasing area under crops, like pulses, having potential to maintain soil fertility and will also take care of widening demand- supply gap. Development of varieties with high yield potential and at the same time, responsive to modern technology is the urgent need to make the crop competitive to alternative crops to check shifting area from former to later. But for the time being, pulses policy should be directed towards bridging gap in yield between potential yield and the yield of demonstration plot and actual farmers field for a temporary relief from escalating prices as there is large differences in yield in three farming situation which is evident from the present study through extensive demonstration programmes. Programmes should also be taken to educate the farmers related to the added advantage of pulses cultivation in terms of maintaining soil fertility, improving productivity of subsequent crops.

\section{Conclusion}

Pulses, in spite of having immense importance in food and nutritional security of millions of poor Indian, per capita per consumption is declining mainly due to recent price escalation arising out of short fall in supply and thereby heavy dependence of import. Development of HYV seeds responsive to modern crop production technology through intensive research is the most vital for long term solution of the present crisis in pulses scenario, but for the time being, bridging the estimated gap in yield between FLD and actual farmer's field measuring $18.10 \%$ through extensive extension programme for dissemination and adoption of newly evolved technology of lentil production particularly, in major lentil growing regions may improve the pulses situation of West Bengal. 


\section{REFERENCES}

Aggarwal, P. K and Kalra, N. (1994). Simulating the effect of climatic factors, genotype, water and nitrogen availability on productivity of wheat: II. Climatically potential yields and optimal management strategies. Field Crops Residue, 38:93-103.

Ali, M. and Gupta, S. (2012). Carrying capacity of Indian Agriculture: Pulses crops, Current Sci., 102(6): 874881.

Ali, M. and Kumar, S. (2007). Pulses: Good option for rainfed area, The Hindu Survey of Indian Agril, 39-41.

Bera, B. K. and Nandi, A. K. (2010). Recent trend of pulses production of West Bengal, The Bangladesh Journal of Agril Econ., 33(1\&2): 83-92.

Bhatia, V. S., Singh, P., Wani, S. P., Chauhan, G. S., Kesava Rao, A. V. R., Mishra, A. K., Sriniuas, K., 2008. Analysis of potential yields and yield gaps of rainfed soybean in India using CROPGRO-Soybean model. Agric. For. Meteorol., 148: 1252-1265.

Bhattacharya, M. (2011). Economic analysis of yield gaps in principal crops in India, Agril Situation in India, 8: 231239

Chandra, Ganesh and Sagar, R. L. (2004). Front line demonstration on sesame in West Bengal. Agric. Extn. Rev., 16 (2): 7-10.

Duwayri, M., Tran, D. V. and Nguyen, V. N. (2000). Reflections on yield gaps in rice production: How to narrow the gaps, In: M. K., Papadimitriou, F. J. Dent Herath (eds) Bridging the yield gap in the Asia-Pacific region, FAO Regional Office for Asia and the Pacific, Bangkok, Thailand.

Evans, L. T. (1993). Crop Evolution, Adaptation and Yield, Cambridge University Press, Cambridge.

Hobbs, P. and Morris, M. (1996). Meeting South Asia's future food requirements from rice-wheat cropping systems: priority issues facing researches in the post green revolution era, Natural Resource Group Paper, 96-101.

Kokate, K. D. and Singh, L. (2013): Harnessing pulses productivity, Division of Agriculture, ICAR, New Delhi.

Kumar Asheesh and Elamathi, S. (2007). Effect of nitrogen levels and rhizobium application methods on yield attributes, yield and economics of black gram (Vigna mungo L.), International Journal of Agril Sci., 3(1): 179
-180 .

Meena, B. L., Meena, R. P., Meena, R. H. and Balai, C. M. (2012). Yield gap analysis of rapeseed and mustard through front line demonstration in agro-climatic zones of Rajasthan, Journal of Oilseed Brassica, 3(1): 51-55.

Mukherjee, N. (2003). Participatory learning and action Concept Publishing Company, New Delhi Pp 63-65.

Naab, J. B., Singh, P., Boote, K.J., Jones, J. W. and Marfo, K. O. (2004). Using CROPGRO-Peanut model to quantify yield gaps in the Guinean Savanna zone of Ghana, Agronomy Journal, 96: 1231-42.

Nin-Pratt, A., Johnson, M., Magalhaes, E., You, L., Diao, X. and Chamberlin, J. (2010). Yield gaps and potential agricultural growth in West and Central Africa, International Food Policy Research Institute.

Pingali, P. L. and Heisey, P. W. (1999). Cereal crop productivity in developing countries: Past Trends and Future Prospects, Economics Working Papers 76-82, CIMMYT: International Maize and Wheat Improvement Centre.

Price, G. K. Landes, R. and Govindan, A. (2003). Electronic Outlook report from the Economic Research Service, WRS-03-01, USDA.

Rajiv and Singh, L (2014). Performance of pulses demonstration Bundelkhand Zone of Uttar Pradesh, India, Indian Journal of App Research, 4(3): 1.

Reddy, A. (2004). Consumption pattern, trade and production potential of pulses. Economic and Political Weekly. October : 4854-60.

Samui, S. K., Mitra, S., Roy, D. K., Mondal, A. K. and Saha, D. (2000). Evaluation of front line emonstration on ground nut (Arachis hypogea L.), Journal of Indian Society of Coastal Agriculture Research, 18: 180-83.

Sarungham, D. and Prasad, E. Y. (2011). An analysis of yield gap in rice production in Manipur, Agril Situation in India, 8: 241-244.

Singh, M. (2001). Sustainability of Rice-Wheat System in Eastern UP: An Economic perspective, Ph.D. Dissertation, IARI, New Delhi.

Vaghasia, P. M, Savalia, R. L. and Kelaiya, G. R. (2005). Evaluation of front line demonstration on groundnut in Saurashtra region of Gujarat, Journal of Oilseeds Research, 22(1): 238-239. 